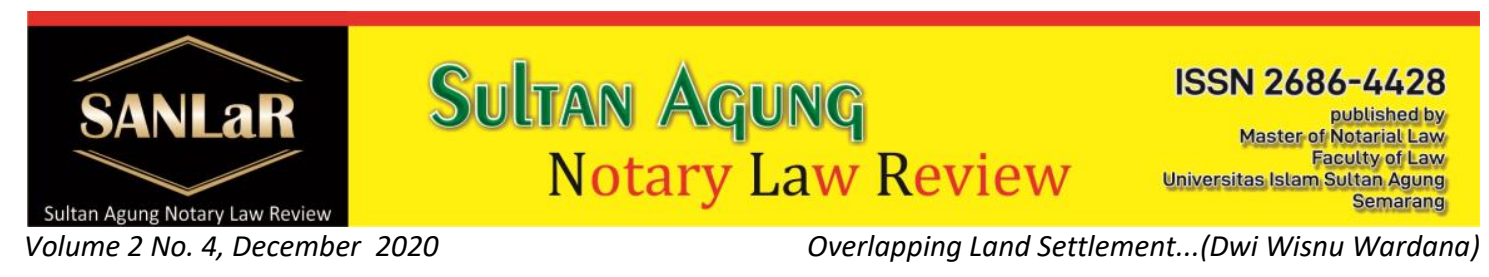

\title{
The Overlapping Land Settlement
}

\author{
Dwi Wisnu Wardana *)
}

*) Student of Master of Notary Law, Faculty of Law, Universitas Islam Sultan Agung (UNISSULA) Semarang, E-mail: dwiwisnu72@gmail.com

\begin{abstract}
The role of Agrarian and Spatial Planning/National Land Agency is very much needed in society to fulfill the need for land services in this part of Indonesia. Considering the importance of a land certificate as a perfect and valid evidence for ownership of land rights, it is necessary to deal with land disputes with a view to ensuring legal certainty of land rights against the right holder or owner. This study is to determine the overlapping resolution in the Office of Agrarian and Spatial Planning/National Land Agency of Surakarta City over land use rights (HP) in Purwodiningratan Surakarta number 36 on behalf of the Surakarta City Government domiciled in Surakarta covering an area of approximately \pm 9,350 $\mathrm{m2}$, with Use Rights ( HP) number 23 on behalf of the Ministry of Transportation of the Republic of Indonesia domiciled in Jakarta (PT. Kereta Api Indonesia) covering an area of approximately $\pm 33,225 \mathrm{m2}$. This research is a descriptive empirical (sociological) juridical research with research data sources derived from primary data and secondary data. the data used includes; interviews, field observations and literature study in the form of books, laws and regulations, documents etc. $h$ The research results that have been collected are then analyzed qualitatively. This study aims: 1) To determine to analyze overlapping land settlement. 2) To find out the obstacles and solutions in overlapping land settlement. 3) To analyze to find legal certainty due to overlapping. Many obstacles to overlapping land settlement in the settlement of Hak Pakai land, especially those belonging to government agencies, are constrained by the bureaucracy of rights holders. The efforts and solutions for the settlement of overlapping land mediation by the Land Office of Surakarta City, in this case, are very dependent on the holders of Land Rights in the settlement of the Land Office as a mediator in the settlement in accordance with statutory regulations.
\end{abstract}

Keywords: Overlapping; Dispute; Mediation.

\section{Introduction}

A dispute is a conflict which can be in the form of a disagreement or interest which can end in a lawsuit or legal claim, conflict is basically a law of cause and effect, where human interaction occurs in life demanding that the concept of difference and similarity is what causes disputes.1. Basically all types of agrarian conflicts arise as a result of gaps related to agrarian resources, especially in the form of land tenure,

1Hasyim, HA. Dardiri. (2016). Hukum Arbitrase. Surakarta: UNS Pres. page 1. 
designation, perceptions and conceptions, as well as conflicting and overlapping laws and policies. ${ }^{2}$

A dispute is a situation where a party feels aggrieved by another party. The party who feels aggrieved conveys this dissatisfaction to the second party and if the second party does not respond to and satisfies the first party, and shows differences of opinion, then what is called a dispute occurs. 3 In line with the principles contained in Land Registration, the objectives to be achieved from the land registration shall be further regulated in Article 3 PP Number 24/1997, stated land registration with the aim; ${ }^{4}$

a. Providing legal certainty and legal protection to holders of land rights, owners of apartment units, holders of Mortgage Rights, so that they can easily prove that they are the holders of the rights concerned.

b. Providing information to interested parties, including the government, in order to obtain the data needed to carry out legal actions regarding registered land parcels and apartment units.

c. To maintain an orderly land administration.

Agrarian/land issues basically all types of conflicts arise as a result of gaps related to agrarian sources, especially in the form of gaps in land tenure, designation, perceptions and conceptions, as well as conflicting or overlapping laws and policies. ${ }^{5}$

Article 3 paragraph (1) Government Regulation number 24 of 1997 that "The purpose of land registration is to provide legal certainty and legal protection to holders of rights over a land parcel so that they can easily prove themselves as holders of the rights concerned" but what happens in society is still There is also a problem of overlapping land rights, so that the overlapping of land rights does not provide legal certainty, as stated in the purpose of land registration as referred to in the Prevailing Laws.

Recognizing the function of the government trying to make breakthroughs with reforms in serving the community, this is expected to support services, improve institutional performance, regulate land registration, provide the best possible public service, improve performance governance, and credible bureaucratic apparatus resources.

The objectives of this study are 1) To determine to analyze overlapping land settlement. 2) To find out the obstacles and solutions in solving overlapping lands. 3) to analyze to find legal certainty due to overlapping.

For example in finishing overlapping land rights. Agrarian and Spatial Planning Office/National Land Agency of Surakarta City

Located in Purwodiningratan Village, Jebres, Surakarta on the right to use (HP) number: 23, on behalf of the Ministry of Transportation of the Republic of Indonesia (PT. Kereta Api Indonesia) covering an area of approximately $\pm 33,225 \mathrm{~m} 2$. With Land Use Rights (HP) number: 36 , on behalf of the Surakarta City Government, covering an area of approximately $\pm 9,350 \mathrm{~m} 2$.

2 Saputra, Muhammad Ilham. (2015). Reformasi Agraria di Indonesia. Jakarta: Sinar Grafika. page 13

3 Amriani, Nurnaningsih. (2011). Mediation (Alternative Civil Dispute Resolution in Court). Jakarta: Raja Grafindo Persada. p. 12

4 Handoko, Widhi. (2014). Kebijaksanaan Hukum Pertanahan, Sebuah Reffleksi Keadilan Hukum Progresif. Yogyakarta: Thafa Media. p. 240

5 Arisaputra, Muhammad Ilham. (2015). Reformasi Agraria di Indonesia. Jakarta: Sinar Grafika. p. 13 


\section{Research Methods}

This legal research is an empirical or sociological research. Law is an approach by looking at a legal reality in society. ${ }^{6}$ This means that in addition to looking at the juridical aspect of the legal provisions by looking at the statutory regulations and legal provisions, it is also seen from an empirical legal point of view, namely its implementation, so that it can be seen whether there is normative harmony with implementation in the field, research using descriptive methods. namely: "A descriptive study is intended to provide data as accurate as possible about humans, conditions or other symptoms, the intention is mainly to reinforce hypotheses, so that they can strengthen old theories, or within the framework of compiling theories. new".7

\section{Results and Discussion}

\subsection{Right to Use of State Land}

The provisions on the Right to Use (HP) are stated in article 16 paragraph (1) letter $d$ in Law No. 5 of 1960 UUPA, furthermore regarding the special provisions regulated in article 41 to article 43 of the UUPA, while further specific provisions regarding the Right to Use (HP) contained in articles 39 to 58 are regulated in the Regulation of the Minister of Agrarian Affairs/Head of the National Land Agency Number 40 of 1996 concerning the Right to Use the Right to Build the Right to Use the Land (PMA/Ka BPN No. 40/1996).

The Right to Use over state land The Right to Use is granted by the decision of granting rights by the Head of the National Land Agency of the Republic of Indonesia, or Officials of the National Land Agency or those given the delegation of authority. ${ }^{8}$

This provision is regulated in the Regulation of the Minister of Agrarian Affairs/Head of the National Land Agency Number 40 of 1996, Concerning Land Use Rights Building Use Rights (PMA/Ka BPN No. 40/1996), while the delegation of authority is regulated in a Regulation of the Minister of Agrarian Affairs/The Head of the National Land Agency Article 5 Number 2 of 2013 (Permenag/Ka BPN No.2 of 2013) Regarding the Delegation of Authority to Grant Rights to Land and Land Registration Activities, the provisions of this Regulation stipulate that the Head of City/Regency Land Offices has the authority to issue decisions on granting rights Use, while the authority of the Regional Office of the Provincial Land Agency has the authority to issue a decision to grant usage rights as stipulated in article 10.

Whereas in the provisions of Article 10 letter $c$ in the Regulation of the Minister of Agrarian Affairs/Head of the National Land Agency Number 2 of 2013 states;

The Head of the Regional Office of BPN gives a decision regarding;

Granting Use Rights for private legal entities, BUMN/BUMD over non-agricultural land with an area of more than $20.000 \mathrm{m2}$ (twenty thousand square meters) and not more than $150,000 \mathrm{~m} 2$ (one hundred and fifty square meters).

6 Ali, H. Zainudin. (2015). Metode Penelitian Hukum. Jakarta: Sinar Grafika. p. 105

7 Soekanto, Soeryono. (2015). Pengantar Penelitian Hukum. Jakarta: UI Pres. P. 10

8 Santoso, Urip. (2012). Hukum Agraria Kajian Konprehensif. Jakarta: Kencana, page 120 
The procedure for issuing a decision to grant usage rights is regulated in article 50 to article 56 of the Agrarian Minister/Head of BPN No. 9/1999. ${ }^{9}$

\subsection{Causes of OccurrenceOverlapping: ${ }^{10}$}

The occurrence of overlapping (overlapping) can be categorized as 2, namely; overlapping the whole; namely overlapping (overlapping) in which the land parcels overlap as a whole with other land parcels, and partially overlapping (overlapping); that is, only part of the land is shared with other parcels of land.

These things can be caused, among others;

1. Incomplete base map.

The incomplete mapping of land parcels is incomplete on the basic map for land registration (Berwerken) at the Land Office so that mapping of land parcels is only based on measurements in the field when the applicant submits a land measurement.

2. The existence of human error (human error)

a. There is an accidental error from the applicant or power of attorney caused by an error in showing the boundaries of the land parcels at the time of the measurement, by officers from the Land Office because the applicant or the recipient of power by the holder of land rights does not know the exact boundaries of the land parcels. which is actually.

b. The applicant's intention fthe actor deliberately designating the boundaries of the land parcels by the applicant with the intention of personal gain so that the designation of the boundaries of the land parcels is wrong, so that the Land Measurement Letter mapped out the actual boundaries.

3. Owners of rights to bordering land

There are no clear boundaries to the land parcels owned by the owner, paying less attention and not taking good care of the boundaries of the land parcels in maintaining the boundaries of their property, the absence or loss of the upper boundary marks of the land parcels, making it easier to be recognized by other applicants consequently the applicant showed intentionally that the parcel of land belonged to him because he felt that he had occupied it for a long time.

4. National Land Agency Factors

Incomplete previous administrative system, incomplete data on land parcels, either registered or unregistered, in which registration is then carried out recording land registered at the Land Office, as well as in mapping image maps at the Land Office, because the Land Office is passive means only receiving files when there is a request by the applicant.

Particularly in the problem of Overlapping (overlapping), part of this research occurs due to factors:

1. According to data at the Surakarta City Land Office, the Right to Use certificate (HP) number 23 on behalf of the Ministry of Transportation of the Republic of Indonesia domiciled in Jakarta, covering an area of $33,225 \mathrm{~m} 2$, issued by the Land Office of the

9 Santoso, Urip. Ibid p. 121

10 Interview with the Land Office Mr. Agus Siswanto, S.ST. HP overlapping technical team. no. 36/Purwodiningratan, Head of Sub-Division of Cadastral Measurement and Mapping, Surakarta City Land Office, October 1, 2020, at 10.00 WIB. 
City of Surakarta on 31- July - 1996, based on a decree. Head of Regional Office of the National Land Agency of Central Java Province, signed by the Head of the Regional Office of the Central Java National Land Agency Number: 530.3/208/1/355/33/95, dated 13 June 1995 with a Situation Picture/Measurement Letter Number: $3184 / 1996$, dated July 4, 1996, is the result of measurements by the Regional Office of the National Land Agency of Central Java Province with the boundaries of land parcels that have been installed at each boundary point in the form of pieces of railroad iron. it's just that the Land Office of the City of Surakarta, in this case the measurement and mapping section, does not obtain a copy of the image directly from the Regional Office of the National Land Agency of Central Java Province, so it cannot plot the results of the measurements by the Regional Office of the National Land Agency of Central Java Province into base map for the registration of the Surakarta City Land Office. Therefore, the part or area that is the area of Use Rights Number 23/Purwodiningratan Village is still empty or there is no information whatsoever in the base map for registration at the Surakarta City Land Office.

2. There was an accidental error from the applicant in this case the boundary designation assigned by the Surakarta City government in showing the boundaries of the land parcels at the time of the measurement from the Surakarta City Land Office for the issuance of a certificate of Right to Use (HP) Number 36/Kelurahan Purwodiningratan, Jebres, Surakarta, written on behalf of The Surakarta City Government is domiciled in Surakarta, in submitting the measurement designated for Jalan WZ. John, because the boundary markers did not know the boundaries of the actual plot of land.

3.Factual conditions in the field (location) that can lead to overlapping (overlapping) part of the Right to Use (HP) Number: 23/Purwodiningratan and Use Rights (HP) Number 36/Purwodiningratan Village, because physically in the field (location) is in the form of a single unit of road body which has a vital function because it serves as access to Jebres Station, so it is rather difficult to identify and in addition there are already many around the neighborhood that are used as business places by the community on the sides of the road, and the boundaries hidden plots of land between the buildings that have been erected by the community.

With the factors that cause overlapping above, if the problem is not resolved immediately, it will result in problems or problems in the land sector, which of course will result in conflict or dispute.

These factors give rise to land disputes, so that it is the government's duty to require special methods to handle them. The solution to the land dispute problem is done by collecting data on the land in dispute and seeking information about the land. ${ }^{11}$

11 Syarifah Lia Malini Sari, Latifah Hanim, Legal Certainty in Dispute Resolution Overlapping Land Ownership Certificates (SHM) (Case Study at the Office of Land/Agrarian Affairs and Pontianak City Spatial Planning), http://jurnal.unissula.ac. id/index.php/akta/article/view/1552/1197, downloaded 1010-2020, 23.00 WIB. 


\subsection{Problem solving}

As the legal basis for land disputes is the Regulation of the Minister of Agrarian and Spatial Planning/Head of the National Land Agency of the Republic of Indonesia number 11 of 2016, Concerning Settlement of Land Cases, states that "Land Disputes, hereinafter referred to as Disputes, are land disputes between individuals, legal entities or institutions that have no broad impact"

also described in Article 24 of Government Regulation Number 11 of 2016;

"In the event that on one land parcel there is an overlapping certificate of land rights, the Minister of Agrarian Affairs and Spatial Planning/National Land Agency according to its authority issues a decision to cancel the overlapping certificate, so that on the land there is only one valid certificate."

In this study, the Agrarian and Spatial Planning Office/National Land Agency of Surakarta City as the authority for further land settlement based on research and field surveys (location) in the overlapping settlement carried out by the Surakarta City Land Officeover overlapping land in Purwodiningratan Village, Jebres District, Surakarta City, betweenthen to follow up on the findings of overlapping land after checking the boundaries in the field (location) and several studies from the Surakarta City Land Office, then the Surakarta City Land Office published; Minutes of the Results of Corrections and Revisions to the Right to Use Certificate (HP) number 36, located in Purwodiningratan Village, Jebres District, Surakarta City Number: 354/33.72200/I/2018, signed by the Technical Team and Juridis Team, Knowing the Head of the Office Land of Surakarta City.

In an interview with the Surakarta City Land Office; ${ }^{12}$ Certificate of Use Rights Number 36 Purwodiningratan Subdistrict, Jebres District, Surakarta City with Measurement Letter number: 00441/2012, is a written usage right in the name of the Surakarta City Government, domiciled in Surakarta, whose designation is Jalan Wz Yohanes, with a recorded area of 9,350 $\mathrm{m} 2$ (before correction and revisions), are not canceled as meant in Article 24 of the Regulation of the Minister of Agrarian Affairs and Spatial Planning/National Land Agency Number: 11 of 2016, because in the case of overlapping, after being reviewed by the Technical Team and the Judicial Team of the Land Office The city of Surakarta is not entirely overlapping (overlapping) but only OVERLAPPING (TUMPANG TINDIH) PART of the land that overlaps the Right to Use Number 23/Purwodiningratan Urban Village, Jebres District, Surakarta City with Measurement Letter Number:03184/1996, on behalf of the Ministry of Transportation of the Republic of Indonesia domiciled in Jakarta.

legal certainty as a guideline in efforts to regulate law in making laws and regulations made by the competent authority, so that legal certainty has a juridical aspect, law functions regulations that must be obeyed. The main objective in land registration based on PMA/ Ka BPN Number 3 article 3 (a) of 1997 concerning the Implementation of Government Regulation Number 24 of 1997 concerning Land Registration, there is legal certainty for the purposes of:

12 Interview with the Land Office Mr. Ir. Triyono, MM, Head of the Land Office Infrastructure section of Surakarta City, October 1, 2020, at 11.00 WIB. 
"Providing legal certainty and legal protection to holders of land rights, owners of apartment units, holders of Mortgage Rights, so that they can easily prove that they are the holders of the rights concerned."

The researcher hereby links legal theories, in the concept of authority theory Philipus M. Hadjon argues that;

Every government action implies that it must rely on legitimate authority. This authority is obtained through three sources, namely attribution, delegation and mandate. Attribution authority is usually used through the division of state power by law, the authority of delegation is the authority that comes from the attributive delegation of authority, while the mandate does not occur as a delegation of authority. ${ }^{13}$

The Land Office of the City of Surakarta carries out its duties and functions as the competent authority in the settlement of overlapping lands that occurred with the publication of the News. Minutes of the Results of Corrections and Revisions to the Right to Use Certificate (HP) number 36, located in Purwodiningratan Village, Jebres District, Surakarta City Number: 354/33.72-200/1/2018, signed by the Technical Team and Juridis Team, Knowing the Head of the Office Land of Surakarta City.

The certificate is not canceled as referred to in Article 24 of the Regulation of the Minister of Agrarian Affairs and Spatial Planning/National Land Agency number: 11 of 2016, on the Certificate of Use Rights Number 36 Purwodiningratan Village, Jebres District, Surakarta City and Letter of Measurement number: 00441/2012, written on behalf of the Municipal Government of Surakarta, domiciled in Surakarta, which is designated as Jalan Wz Yohanes, with a recorded area of 9,350 m2 (before corrections and revisions). In authority theory;

"Authority or authority is a legal action that is regulated and given to a position based on the prevailing laws and regulations that govern the position concerned ". ${ }^{14}$

According to the concept of authority theory, Philipus M. Hadjon argues that; Every government action implies that it must rely on legitimate authority. The authority is obtained through three sources, namely attribution, delegation and mandate. Attribution authority is usually used through the division of state power by law, the authority of delegation is the authority that comes from the attributive delegation of authority, while the mandate does not occur as a delegation of authority. ${ }^{15}$

In this case the Land Office of the City of Surakarta is in authority over the settlement of overlapping (overlapping) part of the land rights for the Certificate of Use Rights Number 36 Purwodiningratan Village, Jebres District, Surakartan City with Letter of Measurement number: 00441/2012, written on behalf of the Surakarta City Government, Domiciled In Surakarta, where the designation is Jalan Wz Yohanes, with a recorded area of 9,350 $\mathrm{m} 2$ (prior to corrections and revisions), is the authority of the Surakarta City Land Office, so in this provision it is in accordance with its authority in

13 Philipus M.Hadjon. (1997). Penataan Hukum Administrasi, Tentang Wewenang. Surabaya: Fakultas Hukum Unair. p. 2

14 Adjie, Habib. (2008). Hukum Notaris Indonesia, Tafsir Tematik Terhadap UU No.30 Tahun 2004 Tentang Jabatan Notaris. Bandung: Refika Aditama. p. 77

15 M.Hadjon, Philipus. (1997). Penataan Hukum Administrasi, Tentang Wewenang, Surabaya:

Fakultas Hukum Unair. p. 2 
resolving overlapping problems. This answers the explanation in the theory of authority and responsibility assigned to the position,

William Chamblis and Robert B. Seidman theory put forward a theory of the operation of law. In this theory, the operation of law in society is influenced by the power of lawmaking institutions, law enforcement agencies, and social forces, in this case the operation of law cannot be monopolized by law, this theory is used to analyze problems, because this theory is related to the institutions that make it. law, law enforcement, as well as social forces, among others, the political culture of the community.. In the application of the problem of over-lapping (overlapping), this case in this theory is in line with the objectives of Agrarian Reform, namely reducing land disputes and conflicts in realizing harmony in the land sector (settlement of land conflict disputes).

According to Sumardjono's opinion, the 7 dispute resolution mechanisms generally adopted by the National Land Agency (BPN) are as follows: ${ }^{16}$ among them;

a) If an administrative defect is found due to incorrect initial data, then administrative correction will be made by BPN.

b) If the two parties are open to each other, deliberations will be made facilitated by BPN.

c) If the dispute involves sectoral agencies, efforts will be made to coordinate between sectors.

d) If all efforts meet the main failure if the object of dispute is related to rights relating to material truth, then the last resort is through court

On the recommendation of the Technical Team and the Juridical Team in the research and checking in the field (location) it was found overlapping(overlapping) a portion of the Use Rights No.36 of Purwodiningratan Urban Village above the Right to Use Number 23 of Purwodiningratan Urban Village covering an area of 3,750 m2. At the time of the research/field checking, the markers of the Right to Use Land Number 23/Purwodiningratan in the form of REL KA iron pieces that were planted were still in their original position and were in accordance with the picture in the Measure Letter Number: 03184/1996. Based on the results of the research/checking, corrections and revisions were made to the drawing of the land area of the Measure Letter number: 00441/2012 which is an attachment to the Certificate of Use Rights Number 36 of Purwodiningratan Village and adjusted to the boundaries adjacent to the land parcel of the Right to Use Certificate Number 23 Kelurahan Purwodiningratan which resulted in a wide change from 9. $350 \mathrm{~m} 2$ minus the overlapping area of $3,750 \mathrm{~m} 2$ with a new area of 5,600 m2. From the results of the reports from the Technical Team and the Juridical Team, an Official Report on the Results of Corrections and Revisions to the Certificate of Use Rights (HP) number 36 was issued in Purwodiningratan Village, Jebres District, Surakarta City Number: 354/33.72-200/I/2018 signed by the Technical

16 Rizki Riolita, Juridical Analysis of Penal Mediation in Settling Land Disputes Against Double Certificates in the Semarang City Land Office, IJCLS I (1) (2016) Indonesia Journal Of Criminal Law Studies (IJCLS), https://journal.unnes.ac.id/nju/index.php/ijcls/article/download/10805/6585, downloaded 1910-2020, 
Team and the Juridical Team, Knowing the Head of the Surakarta City Land Office as a decision in resolving legal certainty in overlapping cases.

The authority to resolve disputes in the event of certificate cancellation in which there is an administrative flaw can be exercised by BPN and/or the authority can be exercised in the form of delegation to the Head of the Regional BPN Office in canceling the overlapping certificate. Certificate cancellation dispute resolution is regulated in the Minister of Agrarian Regulation No. 11 of 2016 concerning Settlement of Land Cases. Apart from the provisions above, to create good governance, especially for government officials, the law on government administration no. 30/2014 can also be used as a legal basis to base decisions and/or actions of government officials to meet the legal needs of the community in resolving disputes or problems that occur in the community. ${ }^{17}$

The Land Office of Surakarta City, in resolving partially overlapping lands, is experiencing obstacles and obstacles, among others; ${ }^{18}$

1. Land overlapping (overlapping) is partially located in Purwodiningratan Village, Jebres District, Surakarta City, between Right to Use (HP) land number 23 in the name of the Ministry of Transportation of the Republic of Indonesia, domiciled in Jakarta, covering an area of approximately $\pm 33,225$ m2, with Hak Pakai (HP) number 36 in the name of the Surakarta City Government domiciled in Surakarta covering an area of approximately $\pm 9,350 \mathrm{~m} 2$ of which the right on the land the right holder belongs to the government agency, of course, this bureaucratic problem causes internal obstacles and obstacles in the settlement of overlapping land, including; in terms of who is in authority, who is given the task of resolving, and who is given the power to resolve and coordinate in the government it is the determinant of the quick completion of the problem. In the settlement, the Surakarta Land Office coordinates with land object parties which partially overlap in the case of; direct checking on the object of the problem, researching juridical data, checking the land map, re-measuring, designating the boundaries of the land parcels by the parties concerned, this coordination problem is of course an obstacle to the speed of problem solving.

2. Other obstacles that make the problem solving slow overlapping This is related to work that is technical in nature, namely the identification of overlapping land parcels so that they can be plotted/drawn into the image of the land parcel both in the image of the land parcel of the Right to Use (HP) Number 23, and the Right to Use (HP) Number 36/which is located in Purwodiningratan, for obtain a valid area in areas that become overlapping (overlapping).

17 Sahnan, M. Arba, L. Male entrepreneur Suhartana, Kewenangan Badan Pertanahan Pertanahan Nasional dalam penyelesaian sengketa pertanahan, https://jurnalius.ac.id/ojs/index.php/jurnallUS/article/view/714/pdf 131, downloaded 22-10-2020, at 09.00 WIB.

18 Interview with the Land Office Mr. Agus Siswanto, S.ST. HP overlapping technical team. no. 36/Purwodiningratan, Head of Sub-Division of Cadastral Measurement and Mapping, Surakarta City Land Office, October 1, 2020, at 10.00 WIB. 


\section{Closing}

The happening overlapping (overlapping) in this study due to There was an accidental error from the applicant, in this case the boundary designation assigned by the Surakarta City government in showing the boundaries of the land parcels at the time of the measurement from the Surakarta City Land Office for the issuance of the Right to Use (HP) certificate Number: 36/Kelurahan Purwodiningratan, Jebres, Surakarta. written on behalf of:The Surakarta City Government is domiciled in Surakarta, in submitting the measurement designated for Jalan WZ. John, because the boundary markers did not know the boundaries of the actual plot of land.

\section{References}

Books:

[1] Adjie, Habib. (2008). Hukum Notaris Indonesia, Tafsir Tematik Terhadap UU No.30 Tahun 2004 Tentang Jabatan Notaris. Bandung: Refika Aditama.

[2] Ali, H. Zainudin. (2015). Metode Penelitian Hukum. Jakarta: Sinar Grafika.

[3] Amriani, Nurnaningsih. (2011). Mediation (Alternative Civil Dispute Resolution in Court). Jakarta: Raja Grafindo Persada.

[4] Arisaputra, Muhammad Ilham. (2015). Reformasi Agraria di Indonesia. Jakarta: Sinar Grafika.

[5] Handoko, Widhi. (2014). Kebijaksanaan Hukum Pertanahan, Sebuah Reffleksi Keadilan Hukum Progresif. Yogyakarta: Thafa Media.

[6] Hasyim, HA. Dardiri. (2016). Hukum Arbitrase. Surakarta: UNS Pres.

[7] M.Hadjon, Philipus. (1997). Penataan Hukum Administrasi, Tentang Wewenang, Surabaya: Fakultas Hukum Unair.

[8] Philipus M.Hadjon. (1997). Penataan Hukum Administrasi, Tentang Wewenang. Surabaya: Fakultas Hukum Unair.

[9] Santoso, Urip. (2012). Hukum Agraria Kajian Konprehensif. Jakarta: Kencana.

[10] Saputra, Muhammad IIham. (2015). Reformasi Agraria di Indonesia. Jakarta: Sinar Grafika.

[11] Soekanto, Soeryono. (2015). Pengantar Penelitian Hukum. Jakarta: UI Pres. 
Internet:

[1] Syarifah Lia Malini Sari, Latifah Hanim, Legal Certainty in Dispute Resolution Overlapping Land Ownership Certificates (SHM) (Case Study at the Office of Land/Agrarian Affairs and Pontianak City Spatial Planning), http://jurnal.unissula.ac. id/index.php/akta/article/view/1552/1197, downloaded 10-10-2020, 23.00 WIB.

[2] Sahnan, M. Arba, L. Male entrepreneur Suhartana, Kewenangan Badan Pertanahan Pertanahan Nasional dalam penyelesaian sengketa pertanahan, https://jurnalius.ac.id/ojs/index.php/jurnallUS/article/view/714/pdf 131, downloaded 22-10-2020, at 09.00 WIB.

[3] Rizki Riolita, Juridical Analysis of Penal Mediation in Settling Land Disputes Against Double Certificates in the Semarang City Land Office, IJCLS I (1) (2016) Indonesia Journal Of Criminal Law Studies (IJCLS), https://journal.unnes.ac.id/nju/index.php/ijcls/article/download/10805/6585, downloaded 19-10-2020, at 21.00 WIB.

Interview:

[1] Interview with the Land Office Mr. Agus Siswanto, S.ST. HP overlapping technical team. no. 36/Purwodiningratan, Head of Sub-Division of Cadastral Measurement and Mapping, Surakarta City Land Office, October 1, 2020, at 10.00 WIB.

[2] Interview with the Land Office Mr. Agus Siswanto, S.ST. HP overlapping technical team. no. 36/Purwodiningratan, Head of Sub-Division of Cadastral Measurement and Mapping, Surakarta City Land Office, October 1, 2020, at 10.00 WIB.

[3] Interview with the Land Office Mr. Ir. Triyono, MM, Head of the Land Office Infrastructure section of Surakarta City, October 1, 2020, at 11.00 WIB. 